Modern Asian Studies 49, 4 (2015) pp. 1091-1 121 . (C) Cambridge University Press 2014 doi:10.1017/Soo26749X13000528 First published online 20 May 2014

\title{
Showing One's Colours: The political work of elections in post-war Sri Lanka*
}

\author{
BART KLEM \\ Department of Political Geography, University of Zurich, Switzerland \\ Email:bart.klem@geo.uzh.ch
}

\begin{abstract}
This article analyses Sri Lanka's April 2010 parliamentary elections as they played out in the Muslim community on the east coast. The political work of elections, as the article shows, involves a lot more than the composition of government. Antagonism over group identities and boundaries are at centre stage. Elections force people to show their colours, which causes turbulence as they grapple with several, possibly contradictory, loyalties. The article argues that elections bring together different political storylines, rather than one master antagonism. It is the interaction between different narratives that paradoxically provides elections both with a sense of gravity and dignity, and with the lingering threat of rupture and disturbance.
\end{abstract}

\section{Introduction}

This article analyses the evolution of the 2010 parliamentary elections in Trincomalee, a peripheral district on Sri Lanka's east coast. It conceptualizes elections as a powerful political moment of ritual and spectacle in which more fundamental societal narratives converge and collide. By exploring the politics of a particular community-Sri Lanka's second largest minority: the Muslims-in the immediate postwar context, the article foregrounds the dynamics of crafting group boundaries, moral communities, and vertical loyalties. And it argues

* For valuable help during the field research, the author would like to thank Shahul Hasbullah, Jasmy, and Mubarak. Mr Ajiwadeen's archival research is also gratefully acknowledged. Many thanks are also due to Mukulika Banerjee, Ward Berenschot, Sarah Byrne, Georg Frerks, Timmo Gaasbeek, Urs Geiser, Benedikt Korf, Jonathan Spencer, and two anonymous reviewers who provided constructive feedback on earlier drafts of this article. For help with the drafting of the map, I am indebted to Marc Vis. 
that it is these contentions that account for the state of excitement, the intrigue, and the sense of anxiety that elections tend to evoke.

The political work that elections do reaches well beyond the electoral moment itself. Elections do not just bring about the composition of a new parliament. They involve the active crafting, activating, and rearranging of political identities. This conceptualization emerges from a set of recent ethnographic forays into democratic politics. ${ }^{1}$ My main point of reference lies with Jonathan Spencer's work on politics, violence, and the state in South Asia. ${ }^{2}$ Steering clear of the cold arithmetic that often characterizes electoral studies, Spencer posits that elections are 'moral dramas of identity and difference'. They produce and reproduce antagonistic political identities, thus activating boundaries between 'us' and 'them'. They dramatize collective citizenship, but they also expose divisions, thus opening a register of disturbance and transgression.

My emphasis on antagonism and identity politics does not imply that more rational or interest-based dimensions of politicsbe they consensus-seeking or clientelism-are irrelevant. But, to adopt Mukulika Banerjee's phrasing, a purely interest-based or functionalist understanding of politics is a little 'threadbare'. ${ }^{4}$ Such an understanding is poorly positioned to engage with the powerful performative and carnivalesque dimensions of politics. Putting political identities and antagonism at the heart of our analysis helps to explain why people invest energy in politics, even when they are unlikely to receive many benefits from their politicians. And it brings

\footnotetext{
${ }^{1}$ M. Banerjee (2008) 'Democracy, Sacred and Everyday: An Ethnographic Case from India', in J. Paley (ed.) Democracy: Anthropological Perspectives, Santa Fe: School of Advanced Research Press, pp. 63-95; M. Banerjee (2011) 'Elections as Communitas', Social Research, 78 (1), pp. 75-98; W. Berenschot (2011) Riot Politics: Hindu-Muslim Violence and the India State, London: Hurst; R. Bertrand, J.-L. Briquet and P. Pels (eds) (2007) Cultures of Voting: The Hidden History of the Secret Ballot, London: Hurst; J. Cupples (2009) 'Rethinking Electoral Geography: Spaces and Practices of Democracy in Nicaragua', Transactions of the Institute of British Geographers, NS 34, pp. 110-124; J. Harriss, K. Stokke and O. Törnquist (eds) (2004) Politicising Democracy: The New Local Politics of Democratisation, Basingstoke: Palgrave; J. Paley (ed.) (2008) Democracy: Anthropological Perspectives, Santa Fe: School of Advanced Research Press.

${ }^{2}$ J. Spencer (2003) 'A Nation "Living in Different Places": Notes on the Impossible Work of Purification in Postcolonial Sri Lanka', Contributions to Indian Sociology, 37 (1), pp. 1-23; J. Spencer (2007) Anthropology, Politics and the State: Democracy and Violence in South Asia, Cambridge: Cambridge University Press; J. Spencer (2008) 'A Nationalism without Politics? The Illiberal Consequences of Liberal Institutions in Sri Lanka', Third World Quarterly, 29 (3), pp. 611-629.

${ }^{3}$ Spencer, Anthropology, Politics and the State, p. 78.

${ }^{4}$ Banerjee, 'Democracy, Sacred, and Everyday', p. 73.
} 
to the fore that South Asia's more troubling forms of contestationranging from election violence to communal riots, pogroms, and even war-are not altogether antithetical to democratic politics, but closely related to it.

These explorations in political anthropology resonate with the case discussed in this article. Political identity issues featured saliently in Sri Lanka's 2010 parliamentary elections. The polls provided an occasion for people to define themselves in relation to others (us and them) and in relation to the state (citizens of a democratic nation). The importance of group boundaries may seem straightforward in the Sri Lankan context. Given that the island recently emerged from nearly three decades of armed separatist conflict fought along ethno-political lines, one would be surprised not to find a measure of antagonism between Sinhalese, Tamils, and Muslims during the first post-war elections. While these fault lines indeed play a salient role, ethnic othering is only part of the story. There are several other forms of antagonism and political identifications, driven by personal ties, townbased rivalries, and the enactment of national citizenship. People belong to more than one 'us' in relation to more than one 'them', and there is a substantial amount of reshuffling in terms of which 'friends' will engage with which 'foes'. The force field between different political loyalties and antagonisms stands at the core of the electoral dynamics I encountered. Elections temporarily intensify interactions between the nation, different group identities, and the individual. This accounts for elections' sense of gravity. The casting of an individual opinion becomes an act of citizenship. And it accounts for the fear of rupture that elections bring. People need to show their colours, but they cannot satisfy all their loyalties with only one vote.

This case study makes a more fundamental point about the complexity of political landscapes and the need to take multiple political identities seriously. The powerful role of such identitiesbe they based on religion, ethnicity, caste, place, nationality or otherwise-is acknowledged in scholarly work on Sri Lankan politics ${ }^{5}$ and, more widely, in the literature on South Asia, a region troubled

${ }^{5}$ J. Uyangoda (2005) 'Ethnic Conflict, Ethnic Imagination and Democratic Alternatives for Sri Lanka', Futures, 37, pp. 959-988; R. Venugopal (2009) 'Cosmopolitan Capitalism and Sectarian Socialism: Conflict, Development, and the Liberal Peace in Sri Lanka', PhD thesis, University of Oxford; N. Wickremesinghe (2006) Sri Lanka in the Modern Age. A History of Contested Identities, London: Hurst. 
by exclusivist ideologies like Hindutva and communal riots, ${ }^{6}$ caste politics, ${ }^{7}$ and separatist struggles. ${ }^{8}$ This article seeks to complement the scholarly record on political contestation in South Asia by bringing to the foreground the interaction between different identity struggles. Although ethnic division remains the most prominent political cleavage, it is severely complicated by other kinds of usthem divisions, certainly in Trincomalee, but plausibly in many other parts of South Asia as well. A lot of political effort is invested in arranging the different forms of antagonism, in (re)enacting identities and (de)activating boundaries, and it is that kind of work that elections do.

Preceded by a brief conceptual and contextual background, the core of this article comprises a chronological account of the elections in Trincomalee's Muslim pockets. The fieldwork underpinning this article was done in the period January to May 2010, but builds on a longer term engagement with eastern Sri Lanka and more or less annual field visits over the past decade. ${ }^{9}$

\section{The political work of elections: defining ourselves, our others, and the state}

Spencer's inspiring exploration of 'political modernity' in South Asia ${ }^{10}$ weaves together a broad intellectual canvas-traversing questions of

\footnotetext{
${ }^{6}$ Berenschot, Riot Politics; P. Brass (2003) The Production of Hindu-Muslim Violence in Contemporary India, Seattle: University of Washington Press; T. Hansen (2001) Wages of Violence: Naming and Identity in Postcolonial Bombay, Princeton: Princeton University Press; H. Spodek (2010) 'In the Hindutva Laboratory: Pogroms and Politics in Gujarat, 2002', Modern Asian Studies, 44 (2), pp. 349-399; S. Tambiah (2005) 'Urban Riots and Cricket in South Asia: A Postscript to "Leveling Crowds"', Modern Asian Studies, 39 (4), pp. 897-927; S. Wilkinson (2004) Votes and Violence: Electoral Competition and Ethnic Riots in India, Cambridge: Cambridge University Press.

${ }^{7}$ A. Doron (2010) 'Caste Away? Subaltern Engagement With the Modern Indian State', Modern Asian Studies, 44 (4), pp. 753-783; D. Roy (2012) 'Caste and Power: An Ethnography in West Bengal, India', Modern Asian Studies, 46 (4), pp. 947-974.

${ }^{8}$ L. Gayer and C. Jaffrelot (eds) (2009) Armed Militias of South Asia: Fundamentalists, Maoists, and Separatists, New York: Columbia University Press.

${ }^{9}$ The fieldwork in 2010 comprised 136 interviews (in English or with translation), observations of election rallies, speeches and so-called pocket meetings, perusal of (English language) newspapers, and archival research on Trincomalee's electoral history (by Mr Ajiwadeen). All quotes in this article are taken from these interviews, unless otherwise attributed.

${ }^{10}$ Spencer, Anthropology, Politics and the State, p. 3.
} 
democracy and secularism; citizenship, nationalism and the nationstate; war and peace-with reflections on 'the political'. He draws on scholarly proponents of 'radical democracy' who revisit the intellectual legacy of the German political theorist Carl Schmitt to argue that a deliberational and consensus-oriented understanding of democracy overlooks the very essence of politics. ${ }^{11}$ Adversarial positions are not just the result of clashing interests (which could be addressed with rational problem-solving), they are at the heart of what politics is. Antagonism between us and them, so the argument goes, is constitutive of politics. This takes us beyond the space of formal politics and directs us to more existential and morally charged questions around how people define themselves politically.

Debates on 'the political' have strong Western antecedents, but Spencer posits that the central idea has great purchase on political contestation in South Asia. This becomes particularly clear in his discussion of electoral politics-'dramas of identity and difference'with which I engage in this article. Importantly, political identities are not merely expressed during elections, they are enacted through them. ${ }^{12}$ Elections involve hard political work-to reify identities, to perform registers of loyalty and belonging, and to activate (or deactivate) social boundaries. It is these processes that make elections such a turbulent and potentially disturbing phenomenon. In Spencer's words, 'the carnivalesque space of the political is a space of possibility and licence: licence to argue, and licence to joke, and licence to experiment with challenges to the order of things. It is, for this reason, also a space of danger, anxiety, and concern. ${ }^{, 13}$

Although Spencer leaves this somewhat implicit, such an interpretation requires us to depart from the rigid dichotomies that typify the radical democracy debate, which foregrounds antagonism along the received left-right spectrum. There are several kinds of us and several kinds of them. It is a common theme in Sri Lankan politics, and elsewhere in South Asia, that the politics of caste, class, ethnicity, religion, ideology, and regional disparity-to name the most salient examples-often produce different kinds of cleavages. In Sri Lanka, the common wisdom is that ethnicity trumps class, caste, and

\footnotetext{
${ }^{11}$ Common references include: E. Laclau and C. Mouffe (1985) Hegemony and Socialist Strategy: Towards a Radical Democratic Politics, London: Verso; C. Mouffe (2005) On the Political, London: Routledge.

${ }^{12}$ Spencer, Anthropology, Politics and the State, pp. 76-78.

${ }^{13}$ Spencer, Anthropology, Politics and the State, p. 94.
} 
region, and partly because of that, the island became entangled in an ethno-secessionist war. While this is largely true, other identities, boundaries, and political antagonisms have clearly not disappeared. ${ }^{14}$ Contestation along other-than-ethnic lines severely complicates the political picture, and-importantly-this not only causes academic head scratching; it is, in fact, an acute challenge for voters too.

While contradictory loyalties evoke a sense of anxiety and possible rupture, the bringing together of different identities also dramatizes the bond between citizens and their state. This provides electoral performance with ritual qualities and a sense of gravity. Villages suddenly matter to the nation. Powerful people act out their bonds with the community. People's individual vote becomes an act of citizenship, which some of them take on as a duty of nearly religious proportions. In this connection, Banerjee coins the term 'sacred elections' in her ethnography of elections in West Bengal, India. ${ }^{15}$ Seen from such a ritual perspective, electoral performance not only bestows on voters an aura of prominence, it also affirms the legitimacy of the political system. Elections, in other words, can also be understood as a form of subjectivation. They turn people into registered voters, and thus subjects of state rule. ${ }^{16}$

Spencer's phrase 'drama of unity and difference' is well chosen, because it covers both aspects of elections. On the one hand, it captures the spectacle, intrigue, and transgression around antagonistic identities. And, on the other hand, it alludes to the dignified performance of citizenship that affirms the indivisibility and righteousness of the system. As we will see below, in the case of Trincomalee's Muslims, people need to show their colours during elections and this evokes partly overlapping and partly contradictory narratives of loyalty and belonging.

\section{Identity politics in Sri Lanka}

The case discussed in this article is something of an anomaly. First of all, Sri Lanka is one of just a few countries where elections and democratic changes of government continued despite protracted

\footnotetext{
${ }^{14}$ Venugopal, 'Cosmopolitan Capitalism'; Wickremesinghe, Sri Lanka in the Modern Age.

${ }^{15}$ Banerjee, 'Democracy, Sacred, and Everyday'.

${ }^{16}$ Bertrand, Briquet and Pels, Cultures of Voting.
} 
armed conflicts, most obviously the Tamil separatist war in the northeast (1980s-2009), but Sinhala Marxist uprisings elsewhere in the country as well (1970s and 1980s). Secondly, the elections of April 2010 were unique. They were the first parliamentary elections to take place after the war and, unlike many other elections, it was more or less clear from the start that the Rajapaksa government would win, riding high on its military victory and Sinhala patriotism. Thirdly, the article focuses on the Muslim community, which does not normally feature saliently in political analyses of Sri Lanka. This article thus tells the story of a particular population group, in a particular country, at a particular time. However, the central pointabout people having to show their political colours and the flurry of socio-political behaviour that stems from this-is more fundamental. It sheds light on the nature of politics in Sri Lanka and it resonates with political contestation in other parts of the world.

The problematic relationship between Sri Lanka's democratic politics and Tamil separatism is well studied. ${ }^{17}$ The island inherited its political infrastructure from British colonial rule, but electoral dynamics after independence developed a distinct ethno-nationalist tone. The perceived need to redress the colonial grievances of the Sinhala majority $(73 \text { per cent })^{18}$ resulted in pro-Sinhala policies. The two main parties - the United National Party and its early breakaway faction, the Sri Lanka Freedom Party-meanwhile developed a ferocious rivalry, which not only resulted in alternating capitalist (United National Party) and socialist (Sri Lanka Freedom Party) orientations, but also in competitive Sinhala nationalism. The Tamil minority (13 per cent) parties gradually shifted from advocating minority rights to outright separatism, which then evolved into the protracted civil war between the government and the Liberation Tigers of Tamil Eelam (hereafter LTTE).

The introduction of a proportional representation system and a powerful executive presidency in 1978 ended the supremacy of the two mainstream parties to the benefit of the smaller ones-each with a distinct ethnic profile-who became 'kingmakers', capable of

${ }^{17}$ S. Bastian (2005) 'Electoral Systems and Political Outcomes', Law and Society Trust Review, 15 (210), pp. 18-25; Uyangoda, 'Ethnic Conflict'; Venugopal, 'Cosmopolitan Capitalism'; Wickremesinghe, Sri Lanka in the Modern Age.

${ }^{18}$ Population statistics are based on the author's calculations, using 2007 census data taken from: Department of Census and Statistics (2007) 'Basic Population Information on Trincomalee District-2007, Preliminary Report Based on Special Enumeration-2007' [ISBN 978-955-577-616-5]. 
tipping the balance in favour of either mainstream party. Proportional representation, however, bolstered the salience of Sinhala nationalism and led to unstable coalition politics, which continued to exclude minority parties that were unwilling to trade their principles for patronage. ${ }^{19}$ This tendency was reinforced by the introduction of preferential votes and the creation of a national list (of unelected members of parliament that were assigned by the biggest parties), which shifted importance to individual members and their ability to cross over.

\section{Muslim politics}

With about 1.6 million people, the Muslim community forms Sri Lanka's second-largest minority (9 per cent). They live dispersed across the country, but some of the largest Muslim settlements are located in the east. The Muslims have close cultural and linguistic links with the Tamils, but the escalation of ethnic violence in the 1980 and 1990 drove a wedge between the two communities. After decades of Sinhala and Tamil nationalism, the Muslims thus joined the fray with their own discourse of ethnic rights and belonging. ${ }^{20}$ The political coming of age of the Muslims was closely associated with the creation of the Sri Lanka Muslim Congress (hereafter the 'Muslim Congress', its common short name) in the early 1980s, and with the proliferation of Islamic reform movements, which bolstered the salience of a Muslim identity. ${ }^{21}$ The formation of the Muslim Congress was also a response to the war. The everyday reality of violence, extortion, and intimidation in the northeast hardened ethnic fault lines and demanded stronger political leadership to speak on behalf of the besieged Muslim community. ${ }^{22}$

${ }^{19}$ Bastian, 'Electoral Systems'.

${ }^{20}$ D. McGilvray (201 1) 'Sri Lankan Muslims: Between Ethno-Nationalism and the Global Ummah', Nations and Nationalism, 17 (1), pp. 45-64.

${ }^{21}$ F. Haniffa (2008) 'Piety as Politics Amongst Muslim Women in Contemporary Sri Lanka', Modern Asian Studies, 42 (2/3), pp. 347-375; B. Klem (201 1) 'Islam, Politics and Violence in Eastern Sri Lanka', Journal of Asian Studies, 70 (3), pp. 730-753; McGilvray, 'Sri Lankan Muslims'.

${ }^{22}$ J. Goodhand, B. Klem and B. Korf (2009) 'Religion, Conflict and Boundary Politics in Sri Lanka', European Journal for Development Research, 21 (5), pp. 679-898; S. Hasbullah and B. Korf (2009) 'Muslim Geographies and the Politics of Purification in Sri Lanka after the 2004 Tsunami', Singapore Journal of Tropical Geography, 30, pp. 248-264; D. McGilvray and M. Raheem (2007) Muslim Perspectives on the Sri Lankan Conflict, Policy Studies 41, Washington DC: East West Center. 
The Muslim Congress inserted a unified Muslim voice into Sri Lankan politics. Although it adopted a more militant Muslim rhetoric, it nonetheless joined whichever party entered government in order to secure ministerial positions and resources. Whereas a principled agenda of Muslim rights worked to unite the Muslim electorate, patronage produced a divisive impulse. After the death of its founding father in 2000, the Muslim Congress could no longer keep its fragmented Muslim pockets together. Rauf Hakeem won the succession struggle, but renegade members of parliament created their own electoral machines: the National Unity Alliance, the National Congress, and the All Ceylon Muslim Congress. Dissent intensified when the Muslim Congress entered opposition benches in 2004, while the various factions joined the government to safeguard benefits for their constituencies.

The tendency to vote for pragmatic, town-based members of parliament did not sit well, however, with Muslim concerns about the peace talks between the insurgent LTTE and the government (in 2002-2003 and in 2006). Muslim leaders played no significant role in the process and this raised acute anxieties. Worried that their political leaders were arranging deckchairs on the Titanic while the future of their community was at stake, young people, academics, religious leaders, and activists called for a more solid, principled defence of Muslim rights and needs. ${ }^{23}$ These concerns persisted when the peace talks collapsed and the war resumed in 2006. The tension between the Muslim rights agenda (minority issues) and 'development' (townbased patronage) continues and this tension accounts for much of the internal fracturing that plagues the Muslim community today. Although the military defeat of the LTTE in May 2009 took away some of the original raison d'être of the Muslim Congress, Muslim anxieties about Sinhala domination, land 'colonization', and the government's military presence have increased. At the same time, the influx of postwar resources and the construction of infrastructure add urgency to their need to be in government. The Muslim polity thus continues to navigate the difficult terrain of a besieged community that lives dispersed between the Sinhala majority and the Tamil minority and cannot afford to completely alienate either.

${ }^{23}$ Klem, 'Islam, Politics and Violence'; McGilvray and Raheem, Muslim Perspectives. 


\section{Ethnic geography and electoral politics in Trincomalee}

Trincomalee is an old harbour town on Sri Lanka's east coast. Most of the District's population lives along the Koddiyar Bay that provides natural shelter to the harbour. As is the case in most of eastern Sri Lanka, one finds alternating Tamil and Muslim settlements along the coastline. Wet rice cultivation has long been a central part of everyday life in these communities; paddy fields typically start right at the edge of town. Moving to the interior, one traverses an open landscape with numerous small pockets of trees, houses, and temples, lying like islands in a sea of paddy fields. Trincomalee's only interior settlement of significance is the predominantly Sinhala town, Kantale. Large parts of the interior comprise late colonial and post-colonial irrigation schemes, which are controversial because they brought a significant population to the hitherto sparsely inhabited interior areas, thus altering the ethnic demography of the region. ${ }^{24}$ What was a predominantly Tamil-speaking area (Muslims and Tamils) has gradually become a tri-ethnic district in the past century comprising 45 per cent Muslims, 29 per cent Tamils, and 25 per cent Sinhalese. ${ }^{25}$ Most of the uncultivated parts of the interior comprise a scrubby jungle which until recently provided shelter for the LTTE. Up until 2006, the Tamil insurgents maintained de facto rule along the coastline of Muthur and Ichchalampattu Division and had significant leverage over civilian life throughout the District. ${ }^{26}$

The Muslim community was heavily affected by the Tamil insurgency. Many of their paddy lands became inaccessible, they were forced to pay 'taxes', and different forms of intimidation, coercion, and kidnapping were an everyday reality. The insecurity of peripheral areas inadvertently bolstered urbanization. Satellite villages were abandoned and the larger Muslim towns became ever-denser homes to the growing Muslim population. The tragedy of the 2004 tsunami caused additional processes of displacement, resettlement, and relocation. Kinniya is a particularly densely populated and almost exclusively Muslim hub. Towns like Muthur, Pulmoddai, Kuchchaveli,

${ }^{24}$ T. Gaasbeek (2010) 'Bridging Troubled Waters? Everyday Inter-ethnic Interaction in a Context of Violent Conflict in Kottiyar Pattu, Trincomalee, Sri Lanka', PhD thesis, Wageningen University.

${ }^{25}$ Data taken from: Department of Census and Statistics (2007) 'Basic Population Information on Trincomalee District-2007'.

${ }^{26}$ B. Klem (2012) 'In the Eye of the Storm: Sri Lanka's Front-Line Civil Servants in Transition', Development and Change, 43 (3), pp. 695-717. 
and Thoppur are also predominantly Muslim, though one will find Tamil pockets in and around these rural towns. Trincomalee town is ethnically mixed; Tampalakamam is largely Tamil. Map 1 sketches the District's ethnic geography and indicates the main population centres.

Most Muslim towns consist of an old centre with a well-established mosque, a respected school, and a main street with shops, traders and some food stalls. These older parts are typically inhabited by a relatively well-to-do class of landowners and people with government jobs, who may do some small-scale farming or fishery on the side. The sprawl of houses around the approach roads is usually of more recent date and home to a class of wage labourers, though modern education has facilitated access to white collar and entrepreneurial jobs as well. Along the beaches, one typically finds communities of fishermen, whose social standing is modest, though boat owners may accumulate significant capital. The Muslim community does not have a caste system, but the perceived hierarchy between livelihoods and associated marriage (and inheritance) practices bear some semblance to one. ${ }^{27}$ These general spatial economic patterns among the Muslim community-though clearly not absolute-are often reflected in micro-level electoral geography. While there is a significant amount of fluctuation, the petit bourgeoisie in the town centres tends to have a leaning towards the United National Party, while neighbourhoods of daily labourers and fishermen have historically lent credence to the supposedly proletarian profile of the Sri Lanka Freedom Party.

The creation of the Muslim Congress, which entered the arena as an advocate of the Muslim cause, has complicated these patterns. It gained especially strong support from the lower classes, particularly those who lived in more peripheral areas, close to the threat of LTTE violence and far away from established political patrons. This is especially clear in Muthur. The town is known as a Muslim Congress bastion, the 'jetty area' in particular, and this is unsurprising. It has large concentrations of wage labourers and fishermen and it was a border town throughout the war: LTTE control over the surrounding forests called for strong Muslim leadership. Finally, it was through the Muslim Congress that constituencies like Muthur, which are not populous enough to elect their own member of parliament, could muster their electoral weight.

${ }^{27}$ Gaasbeek, 'Bridging Troubled Waters?', pp. 107-109. 


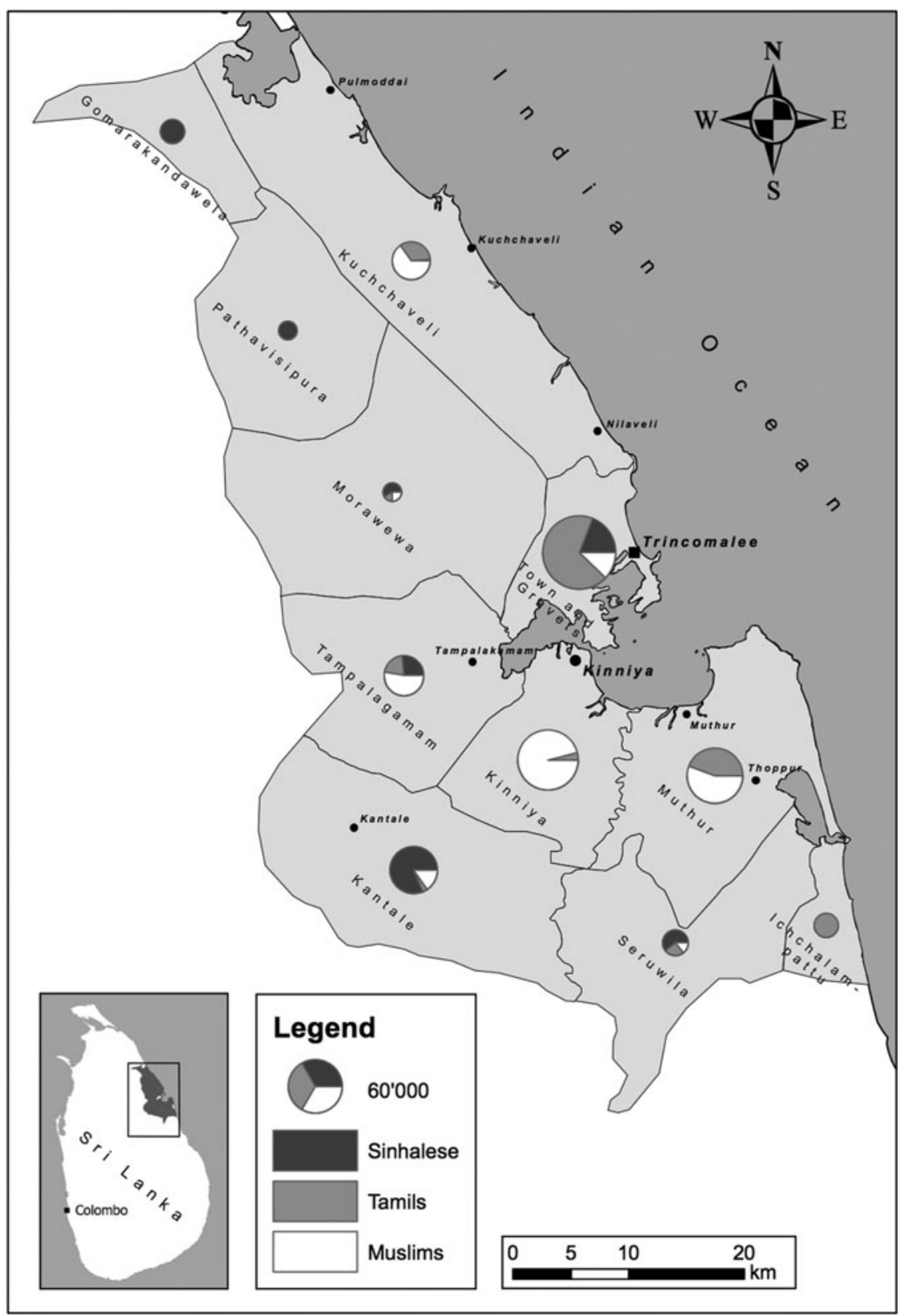

Figure 1. Trincomalee District: population size and ethnic composition per division. 
The one Muslim town that is big enough to secure parliamentary representation-Kinniya-presents an interesting reversion of the class-based electoral geography. The old town, known as Periya (big) Kinniya, is home to land-owning farmers, but is considered a Sri Lanka Freedom Party area, while the fishermen and wage labourers living at the waterfront, in Sinna (small) Kinniya, form a United National Party stronghold. This, my informants explained to me, has everything to do with localized family politics. The Maharoof family, which has been in politics for decades, happens to live in Sinna Kinniya, even though they are very prosperous. They aligned themselves with the United National Party and the neighbourhood largely fell in line with them. In Periya Kinniya, Abdul Majeed became the central political figure in the 1960 s and 1970 . He comes from a very modest background, but did well in school and ended up getting degrees from universities in Mumbai and Chennai. He was a good orator, able to verbalize the Sri Lanka Freedom Party's socialist rhetoric of the time. He also secured access to state largesse and his family is still respected for that reason. Competition between 'political families'-dynasties with an electoral micro-territory-thus complicate the class-based picture, particularly when the Muslim Congress came into play and opportunistic crossovers became centrally important following the introduction of the proportional representation system.

Trincomalee carries some strategic and symbolic significance as a navy harbour and a district situated between the north and east, but this is not reflected in electoral politics. The District's 334,000 inhabitants form a mere $\mathbf{1 . 6 6}$ per cent of the national population. With just four members of parliament out of a 225 -seat parliament, Trincomalee is, in fact, Sri Lanka's least influential electoral district. But although the composition of the four seats is unimportant nationally, people attach great value to it within the local political dynamic (see Table 1 ).

Table 1 provides an overview of the dynamics and outcomes at previous parliamentary elections and confirms some of the above observations. First, the Muslim Congress has been a significant force in the District since its creation. Its alignment with either the Sri Lanka Freedom Party or the United National Party plays a major role in the outcomes of elections. Secondly, the number of Muslim members of parliament varies, but at any given time there is at least one from Kinniya, the District's biggest Muslim town. Thirdly, there are 'political families'. M. E. H. Maharoof represented the prominent Kinniya family until his assassination in the late 1990 . His son Imran 
TABLE 1

Parliamentary elections in Trincomalee District since 1977.

\begin{tabular}{|c|c|c|c|c|c|}
\hline Year & $\begin{array}{l}\text { TULF } \\
\text { (TNA) }\end{array}$ & $\begin{array}{c}\text { SLFP } \\
\text { (PA, } \\
\text { UPFA) }\end{array}$ & SLMC & $\begin{array}{l}\text { UNP } \\
\text { (UNF) }\end{array}$ & MPs (Muslim MPs in bold) \\
\hline 1977 & $\begin{array}{c}27 \% \\
\text { (1 seat) }\end{array}$ & $\begin{array}{c}24 \% \\
(1 \text { seat) }\end{array}$ & $\mathrm{N} / \mathrm{A}$ & $\begin{array}{c}47 \% \\
\text { (1 seat) }\end{array}$ & $\begin{array}{l}\text { - Sampanthan (Tamil, } \\
\text { Trincomalee town TULF) } \\
\text { - MEH Maharoof (Muslim, } \\
\text { Kinniya, UNP) } \\
\text { - Leelaratne (Sinhala, Kantale, } \\
\text { UNP) }\end{array}$ \\
\hline 1989 & $13 \%$ & $23 \%(1)$ & $18 \%$ & $22 \%(1)$ & $\begin{array}{l}\text { - Sivaprakashan (Tamil, } \\
\text { Trincomalee town, } \\
\text { independent) } \\
\text { - Ameer (Muslim, Trincomalee } \\
\text { town, independent) } \\
\text { - MEH Maharoof (Muslim, } \\
\text { Kinniya, UNP) } \\
\text { - Gunawardena (Sinhala, } \\
\text { Kantale, SLFP) }\end{array}$ \\
\hline 1994 & $24 \%(1)$ & $20 \%$ & $22 \%(1)$ & $29 \%(2)$ & $\begin{array}{l}\text { - MEH Maharoof (Muslim, } \\
\text { Kinniya, UNP) } \\
\text { - Ranaweera (Sinhala, Kantale, } \\
\text { UNP) } \\
\text { - Thangathurai (Tamil, Muthur, } \\
\text { TULF) } \\
\text { - Najib Majeed (Muslim, } \\
\text { Kinniya, SLMC) }\end{array}$ \\
\hline 2000 & $11 \%$ & $\begin{array}{r}\text { (PA, incl } \\
40 \%\end{array}$ & $\begin{array}{l}\text { SLMC) } \\
(3)\end{array}$ & $35 \%(1)$ & $\begin{array}{l}\text { - Najib Majeed (Muslim, } \\
\text { Kinniya, PA) } \\
\text { - M.S. Thowfeek (Muslim, } \\
\text { Kinniya, PA) (replacing his } \\
\text { brother Baithulla who was killed by } \\
\text { the LTTE) } \\
\text { - Gunawardena (Sinhala, } \\
\text { Kantale, PA) } \\
\text { - MAM Maharoof (Muslim, } \\
\text { Kinniya, UNP) }\end{array}$ \\
\hline 2001 & 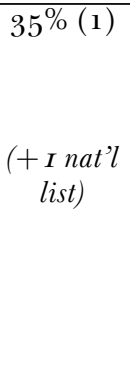 & $20 \%(1)$ & $\begin{array}{c}(+ \text { I nat'l } \\
\text { list })\end{array}$ & $\begin{array}{l}\text { 1. SLMC) } \\
\text { (2) }\end{array}$ & $\begin{array}{l}\text { - Gunawardena (Sinhala, } \\
\text { Kantale, PA) } \\
\text { - Thideer Thowfeek (Muslim, } \\
\text { Muthur, UNF) } \\
\text { - MAM Maharoof (Muslim, } \\
\text { Kinniya, UNF) } \\
\text { National list: } \\
\text { - Thurairathnasingham (Tamil, } \\
\text { Muthur, TULF) } \\
\text { - M. S. Thowfeek (Muslim, } \\
\text { Kinniya, UNF) }\end{array}$ \\
\hline
\end{tabular}


TABLE 1

Continued.

\begin{tabular}{|c|c|c|c|c|c|}
\hline Year & $\begin{array}{l}\text { TULF } \\
\text { (TNA) }\end{array}$ & $\begin{array}{c}\text { SLFP } \\
\text { (PA, } \\
\text { UPFA) }\end{array}$ & SLMC & $\begin{array}{c}\text { UNP } \\
\text { (UNF) }\end{array}$ & MPs (Muslim MPs in bold) \\
\hline 2004 & $37 \%(2)$ & $17 \%(1)$ & $36 \%(1)$ & $9 \%$ & $\begin{array}{l}\text { - Sampanthan (Tamil, } \\
\text { Trincomalee town TULF) } \\
\text { - Thurairathnasingham (Tamil, } \\
\text { Sampur, TULF) } \\
\text { - Najib Majeed (Muslim, } \\
\text { Kinniya, SLMC) } \\
\text { - Jayantha Wijesekara (Sinhala, } \\
\text { Kantale, UPFA) }\end{array}$ \\
\hline
\end{tabular}

Source: Records of the parliamentary library, Kotte. Archival research was carried out by Mr Ajiwadeen.

Note: The parties referred to above are: the Tamil United Liberation Front (TULF), the Sri Lanka Freedom Party (SLFP), the Sri Lanka Muslim Congress (SLMC), the United National Party (UNP), and the United National Front (UNF).

Maharoof contested in 2010 . The rival family is represented by Najib Majeed, son of the famous Abdul Majeed (killed by the LTTE in 1987). Less visible political figures include the English teacher M. S. Thowfeek, who replaced his murdered brother Baithulla in the 2000 polls, and the former physiotherapist Thideer Thowfeek, the only Muslim from Muthur ever to be elected to parliament, a victory he owed at least partially to his marriage: his wife is from Kinniya.

\section{The 2010 parliamentary elections}

What follows is a chronological narrative of the 2010 parliamentary elections in the Muslim pockets of Trincomalee District. There were fairly clear phases in the unfolding script of elections and the text is organized accordingly: the aftermath of the presidential elections, the nomination phase, campaigning, election day, and post-election manoeuvring. As will become clear, the narrative in fact comprises a number of interlacing storylines. The penultimate section will untangle these different political narratives.

\section{Aftermath of the presidential elections}

Mahinda Rajapaksa (Sri Lanka Freedom Party) successfully secured his position at the presidential elections on 26 January 2010 . He had 
scheduled elections early, to capitalize on the government's military victory over the LTTE in May 2009. The campaign became a neckand-neck race when Rajapaksa's former army commander General Sarath Fonseka fell out with the regime and ran for office himself. However, Rajapaksa triumphed with a comfortable margin: $5^{8}$ per cent against 40 per cent for Fonseka. The re-elected government did not waste any time settling scores. Fonseka was arrested and tried in a dubious court case.

The majority of Trincomalee District had voted for Fonseka and people were worried about retribution. The Navy reinstalled a fishing ban (a common occurrence during the war), thus barring a significant portion of the population from eking out a living. In subsequent days, a round of bureaucratic transfers followed. Civil servants whose loyalty to the government was in doubt were sent to less enviable locations. Meanwhile, triumphant Sri Lanka Freedom Party organizers were handing out kiribath (lumpy milk rice, often consumed to celebrate auspicious moments) at their poster-plastered stalls. The tone for the forthcoming parliamentary elections had been set.

\section{Setting the stage: the nomination phase}

Parliamentary polls were still over two months away, but already featured saliently on the rumour circuit and in the newspapers, because candidate lists were being drawn up. This stage of marshalling forces is crucial, because it reorders political alignments. The ethnic background of candidates, the inclusion of respected political families, and the towns they represent strongly affect electoral decisions. People in the District were very familiar with the underlying arithmetic. They started speculating about how many thousand votes from which town were secure for which party or candidate, and how many might swing. The actual bargaining took place in backstage discussions in Colombo. Potential candidates were not sighted in their towns for days or weeks and they would only return for quick consultations with their local advisers, organizers, and sympathizers.

The whole process was complicated, because for each of the potential candidates, success was contingent on the choice of other candidates. After all, the overall composition could unite or split voting blocks. Constituencies wanted their candidate on the list, but too many Muslim candidates would water down the vote. Smaller Muslim pockets like Muthur, Thoppur, Kuchchaveli, and Pulmoddai 
needed to either pool their limited electoral mass or align themselves with a politician from Kinniya. On top of the inter-town dispersion, the community was divided on the aforementioned rights versus development question: whether to vote for the government or the opposition. The majority had voted against Mahinda Rajapaksa during the presidential elections, because they were anxious about Sinhala domination in the region. The leadership of the country's main Muslim party (the Muslim Congress) continued to toe that line, but many voters felt that siding against the government was inadvisable with the Rajapaksas firmly in power.

The gravitational pull of the government became clear to me when I visited a local council chairman in one of the Muslim towns in the District. The nearby road used to be interrupted by ferry crossings, but these were replaced by brand-new bridges after the 2004 tsunami. At one of these bridges, however, travellers were still directed to the rusty ferry next to the bridge. This had more to do with politics than with engineering, the council chairman explained. He had organized a ceremonial bridge opening, but the chief engineer had closed it again, because the chairman was a Muslim Congress politician and thus belonged to the opposition. 'I received calls from SLFP [Sri Lanka Freedom Party] people telling me: "How can you open the bridge? That's a job for the government." [...] The police came and threatened me. Telling me, we have been appointed by the government, so if you go against the government, we can't help you.' The chairman angrily told me the government's days were numbered, because 'the people' were fed up. 'There's no transparency, the cost of living is high, the family influence is too big [he meant Rajapaksa nepotism], there's no space for opposition.' He complained about other Muslim politicians crossing over to the government, serving the petty interests of their own constituency, while jeopardizing the larger cause of the Muslim community.

When I met the council chairman a few weeks later, he had joined the government himself. 'There was no [other] way,' he explained sheepishly. The voters were shifting towards the government. The Muslim Congress, he now thought, was stubborn not to do the same. 'It creates a communal problem. Because the government thinks why should we work for the people who vote for the opposition. [...] There's no way to work against the government. We have no power to stop them. In the opposition, we can't oppose the government.' Weeks later, the prime minister opened the bridge and the council chairman attended the ceremony in the government ranks. He joined the 
campaign of Poonchanilama, a Sinhalese politician from Ratnapura, to whom we will turn below.

On the opposite side of the District, in Muthur, the narrative was almost entirely in sync. 'Opposition is pointless,' a school principal from Muthur told us. He was considering running as a candidate for the National Congress, a Muslim party that had joined the government, and was negotiating with National Congress leader Athaulla. 'But it will be hard here. This is an SLMC [Muslim Congress] area.' To verify his chances, he was meeting with local leaders and representatives of mosques and madrasas. In the end, he decided to withdraw. 'I told the people either we have to be all together or we'll lose. [...] But I concluded that the community was not ready to all unite under one umbrella. Some Muslims would vote [Muslim] Congress; some decided to go with Sinhala candidates of the government. Unfortunately there are three candidates from Muthur. That will split the vote. So I told Athaulla I can't do it. [...] Athaulla said don't worry. I will give you a good position, a chairman of the board or something. But I did not want to do that.'

'Actually I hate politics,' this abortive candidate confided, 'and so does my wife.' Some of his friends advised him not to get into politics. 'They told me I'm not ideal for politics. I'm not ready for the thuggery.' The concern with the 'dirty' business of politics upset him, so much so that he disappeared for the whole election period and went on a pilgrimage in Mecca. 'I was disturbed by the whole thing,' he told me afterwards. This personal sentiment reflects a broader concern that elections and politics cause disturbances, unsavoury arrangements, and threaten the unity of the community. ${ }^{28}$

There was fierce competition between candidates aspiring to have a place on the government list (the United People's Freedom Alliance). ${ }^{29}$ With the electoral mood swinging towards President Rajapaksa, bargaining positions changed. Candidates brokered nominations on less advantageous terms. The main electoral competition shifted from government-opposition antagonism to fierce rivalry between government candidates, who were convinced that the government would win, but were increasingly worried they might not be part of its victory. Tellingly, my respondents had trouble working

\footnotetext{
${ }^{28}$ For discussion, see Spencer, Anthropology, Politics and the State, pp. 79-84.

${ }^{29}$ The United People's Freedom Alliance was a compilation of the Sri Lanka Freedom Party and junior partners. People simply called them 'government', however, and to prevent confusion, so will I.
} 
TABLE 2

The government list.

\begin{tabular}{|c|c|c|c|c|}
\hline Candidate & $\begin{array}{r}\text { Place of } \\
\text { origin }\end{array}$ & Ethnicity & $\begin{array}{l}\text { Party } \\
\quad \text { affiliation }\end{array}$ & Occupation \\
\hline 1. Gunawardana & Kantale & Sinhala & $\begin{array}{l}\text { SLFP } \\
\quad \text { (veteran) }\end{array}$ & $\begin{array}{l}\text { MP, deputy } \\
\text { minister }\end{array}$ \\
\hline 2. $(\mathrm{Mrs})$ Ari Eka & Kantale & Sinhala & SLFP (new) & Businesswoman \\
\hline 3. Najib Majeed & Kinniya & Muslim & $\begin{array}{l}\text { ACMC } \\
(\text { ex-SLMG) }\end{array}$ & $\mathrm{MP}$, minister \\
\hline 4. Niyas & Muthur & Muslim & $\begin{array}{l}\mathrm{NG} \\
\quad(\text { ex-SLMC })\end{array}$ & Givil servant \\
\hline 5. Sabarula & Kinniya & Muslim & $\begin{array}{l}\text { NG } \\
\quad(\text { ex-SLMG) }\end{array}$ & Lawyer \\
\hline $\begin{array}{l}\text { 6. Thideer } \\
\text { Thowfeek }\end{array}$ & Muthur & Muslim & $\begin{array}{l}\text { ACMC } \\
\quad(\text { ex-SLMC) }\end{array}$ & $\begin{array}{l}\text { Council } \\
\text { chairman }\end{array}$ \\
\hline $\begin{array}{l}\text { 7. Poonch- } \\
\text { anilama }\end{array}$ & $\begin{array}{l}\text { Ratnapura } \\
\text { (in the } \\
\text { south of } \\
\text { the } \\
\text { country) }\end{array}$ & Sinhala & $\begin{array}{l}\text { SLFP } \\
\quad(\text { ex-UNP) }\end{array}$ & $\mathrm{MP}$, minister \\
\hline
\end{tabular}

Note: The numerical order of the candidates is alphabetical in the Sinhala alphabet. Source: Interviews and observations.

out the main opposition list (United National Front, encompassing both the United National Party and the Muslim Congress). Typically, they would know the Muslim Congress candidate from their town (M. S. Thowfeek from Kinniya; Harees from Muthur), but had to guess the names of the others. From the Tamil United Liberation Front list, they only knew Sampanthan. Other lists-17 parties and 14 independent groups in total for Trincomalee District-were considered insignificant. The only list that really mattered was the government's (see Table 2).

Competition between two splinter groups of the Muslim Congressthe National Congress and the All Ceylon Muslim Congress-had enabled the government to grant both factions two nominations on the Trincomalee District lists. The other three were given to Sinhala candidates. The majority of government candidates in the District were thus Muslim, but rather than a triumph, this was considered bad news for the Muslim electorate. Their vote would be split between four candidates, while the Sinhala vote would be divided by only three. Similarly, the Muslim candidates were evenly split between two Muslim towns: Kinniya and Muthur. A classic scenario of splitting the vote was about to unfold. 


\section{Canvassing and campaigning}

Now that the cards had been dealt, a much more visible stage started. Streets were plastered with posters of candidates and pictures dramatizing their loyalties and accomplishments. Graffiti was used to spray icons (parties) and numbers (candidates' position on the list). A green tree (the Muslim Congress) with a three referred to M. S. Thowfeek; a blue betel leaf (government) with a seven was Poonchanilama's mark. Rather than a colourful spectrum of voting options, particular streets tended to take on particular colours. Such visual geography thus displayed the prospective strength of certain areas and it was used to undermine others. One local Muslim Congress politician complained to me that someone had sprayed a (government) betel leaf on the parapet wall of his house. Others would chuckle over such pinpricks. 'Elections are like [a] pastime for the community,' a young man from Muthur explained to me. 'Something is happening.' And indeed, it was hard to escape election fever. The slogans, pictures, and advertisements of contenders filled the newspapers; vans with loudspeakers and honking cars would drive around until late at night in otherwise lacklustre neighbourhoods.

Though most heavyweights had joined the government list, the Muslim Congress (the United National Front's main constituent in Trincomalee) still enjoyed support. 'The tree is our religion,' staunch Muslim Congress voters would say, and they would often invoke the Muslim Congress's historic role as a bulwark against the LTTE. Sitting on Muthur's moonlit beach, known Muslim Congress ground, a fisherman rehearsed the area's historic encounters with the LTTE and the government military for us. 'When the end of the war came, we expected to go fishing independently,' he concluded. But the Navy continued to impose fishing bans, the most recent one because the fishermen had voted for the opposition at the presidential polls. He went on:

Now you may think, why don't these people accept that the government has done a lot of help for them. Why don't they just accept the government? That's true. That's how we could think. But the government did not balance the rights of the Sinhalese, the Tamils and the Muslims. For example, if we have a problem with the Sinhalese people and we go to the police, they will support the Sinhalese. [...] they will accept the Sinhalese version of the story. They will always win. That's the only reason we will vote SLMC [Muslim Congress]. The government will always think about the majority.

Muslim Congress candidates and organizers tapped into these sentiments during their 'pocket meetings'. These were the most 
common form of campaigning and targeted the people living around a given junction, typically at dinnertime when people were at home. Party supporters decorated the junction with posters and festoons, and installed loudspeakers to rehearse their key campaign issues, as the local inhabitants gathered at the junction. Those who were less interested or preferred not to be seen (the women, as well as foreign researchers) would quietly listen in from their yards or houses. On one of the United National Front meetings I attended, the speaker alluded to the big battle in Muthur between the LTTE and the Army in 2006:

Then it was only our Muslim brothers who helped us. If the government gets two seats, they will both be Sinhala; if the UNF [United National Front] gets two seats, both will be Muslim. [...] The Sinhalese are encroaching on our land. We need to build a good leadership for the Muslims. Not just development, we also need rights. [... ] Najib [the incumbent candidate from Kinniya] is not active. He is sleeping in parliament. [Names politicians who crossed over to the government] are in place because of their Muslim votes. When they joined the president they went against the Muslim Congress and against the Muslim people. [...] The government has put four Muslim candidates and three Sinhalese. It is a trick to split the Muslim vote.

The next evening, Muthur's government candidate, the senior bureaucrat Niyas (National Congress) organized a slightly bigger pocket meeting on Main Street. Boys and men came over and lingered, sitting on their bicycles and motorcycles. A university lecturer from Kandy added prominence to the occasion. He extolled the government's road-building efforts and discredited Muslim Congress leader Hakeem. 'He will tell you if you vote for [the Muslim] Congress, he'll give you a seat on the national list. But that's a lie. He promises that everywhere. In Oddamavadi, he promises that. In Eravur, he promises that. Everywhere, he says that. In Muthur, he will promise the same thing.' Niyas continued on the same note. 'Hakeem is still not here. If he comes to Muthur, the people will ask him for a place on the national list, but he can't give that. That's the reason he does not come to Muthur.' Then, the speech was cut off by Azan (the call for prayer) and the small crowd dispersed to one of the neighbouring mosques.

In brief, government candidates emphasized the virtues of 'development' (and the Muslim Congress's impotence in delivering largesse), while the Muslim Congress propagated the discourse of Muslim 'rights' (and accused government candidates of squandering these rights). It proved difficult to keep the two apart, though. Muslim Congress candidates would also highlight post-war improvements in 
the infrastructure, but they would try to separate it from government patronage. Government candidates in turn could not let go of the Muslim minority discourse altogether.

My informants discussed these political dilemmas at length, but they spent no less time chatting about the aesthetics of the performance and personal virtues of the candidates. M. S. Thowfeek (Kinniya), for example, was seen as a 'normal' man, uncharismatic but trustworthy. Thideer Thowfeek (Muthur), on the other hand, was seen as a savvy fixer, but partly because of that he was perceived as less dignified. People often hinted at the fact that he tended to drink too much. Najib Majeed (Kinniya) was typically portrayed as incompetent, but commentators would not fail to pay tribute to the credentials of his father Abdul Majeed.

In terms of putting on a show, and displaying political potency, one man seemed to dwarf all these local candidates: Susantha Poonchanilama. While local notables like Niyas were holding their pocket meetings, Poonchanilama toured the District with a whole caravan of buses, vans, three-wheelers, and motorcycles, all decorated with flags, loudspeakers, and banners. On 21 March, the main government rally at the cricket stadium of Trincomalee town started with a massive security presence, followed by helicopters flying in Prime Minister Wickremanayake. The rest of the town was deserted. Inside the stadium, hundreds of spectators listened to the prime minister, who delivered a thundering speech in Sinhala. On the stage behind him sat tens of dignitaries-monks, ulama, priests, senior citizens, and, of course, the government candidates. The familiar kingsize pictures of the president, the bridges, and the power plants to the left and right completed the entourage. Most prominently displayed on these pictures, apart from the president, was Poonchanilama.

Though he was from an entirely different region (Ratnapura), as the district minister for 'nation-building'-the government's main patronage channel to the northeast-Poonchanilama had ample means to show his political muscle. People said that asphalt emerges where he sets foot. Unlike most other candidates, he managed to deliver construction work-roads, electricity supply, drainage—within weeks, if not days. A man from Kinniya summarized the admiration he aroused: 'He's like Spiderman. It's like magic to the people.' Less powerful government candidates like Thideer Thowfeek and Niyas felt overshadowed and spent as much energy preserving their vote base from these 'intruders' as they did discrediting the opposition. Their primary trump card was their connection to the local community. 
'Imran [Maharoof, Muslim Congress] and Najib [Majeed, government] have big families here,' a man from Kinniya explained to me, and their relations would be loyal to them. 'They will get some 1,000 votes just for that.' Such patterns were even clearer in small towns like Muthur where almost everyone knows everyone else, through extended family, school, mosque or work. Muslim Congress candidate Harees was a respected commerce teacher at the Central College and used to preside over the local council: 'everybody knows him'. Nevertheless, a female teacher from Muthur explained that she was inclined to vote for Niyas: 'My brother married his sister. And that sister works in my school.' Thideer Thowfeek was her former classmate. A senior townsman faced a similar situation. He was also related to Niyas, who had, moreover, been one of his students. Thideer Thowfeek was his wife's former classmate. He was not going to vote for them, however, because they had aligned with the government, 'and I'm SLMC [Muslim Congress]'. Personal loyalties thus complicated political orientations to do with the Muslim cause and patronage. He went on to explain that the neighbouring town of Thoppur was particularly divided for this reason. The town has a relatively large land-owning class and significant United National Party and Muslim Congress constituencies, but they also felt indebted to the former Kinniya politician Abdul Majeed. Now that his son Najib had crossed over to the government, some people would 'follow the family', while others would remain loyal to the United National Front (comprising the United National Party and the Muslim Congress).

As election day approached, people were increasingly confident about their predictions. They all agreed on a few counts: the government would secure two of the four seats in Trincomalee District. One of them would be Gunawardana, who had a solid base in the Sinhala-dominated parts of the District: 'He's already selected.' The United National Front would get one seat: most likely M. S. Thowfeek from Kinniya. The Tamil leader Sampanthan (Tamil United Liberation Front) would also get his seat. For my Muslim informants with an interest in politics, there were only two uncertainties left. First, which of the six remaining government candidates would win the second government seat? Andimportantly—would it be a Muslim or a Sinhalese? Second, there was the wild card of the national list. Theoretically, unelected candidates could still be rewarded by their parties.

As the contours of the victories and defeats started to emerge on the map, campaigning dynamics intensified. Last-ditch efforts to 
'break' block votes or tip the balance developed a nastier tone. On the night of 5 April, one of my interlocutors did not turn up. He was stuck in Thoppur, because violence had erupted between government and Muslim Congress supporters. The skirmish prevented Niyas from holding his final rally (electoral protocol disallowed rallies after that night). My informants also reported a clash in Kinniya between supporters of Poonchanilama and Najib Majeed, both of whominterestingly_campaigned on a government ticket. On a different day, government supporters had fallen out with those of Muslim Congress candidate M. S. Thowfeek. These skirmishes were met with a combination of excitement and disapproval. Either way, they were a predictable part of the electoral plot. In fact, my respondents explained, the level of violence was low, compared to other elections, mainly because the government seemed confident it would win. Moreover, the clashes occurred between people who belonged to the same community. 'They are all relatives,' a man from Kinniya reminded me. 'They may argue, but they won't kill each other.'

\section{Election day and results}

And, indeed, despite the skirmishes in the last week before the elections, the atmosphere on election day ( 8 April) was very calm in Muthur, Kinniya, and the surrounding villages. People gradually swarmed to their polling station, often in small groups, taking their children and grannies along. Both men and women turned up, often in separate groups. In each ward or village, a school or other public building had been equipped with polling booths. Policemen guarded the premises and civil servants from all kinds of departments had been recruited for 'election duty' to ensure that the registration, the placing of ink on the voter's fingertip, the voting, and counting was properly done. Public buses were chartered to transport people from remote locations to their polling stations, something of a luxury for these villagers. Voters undertook their franchise as an honourable task. They dressed up and there was a strong sense of duty and dignity in the way they arrived at the polling stations, voted, and departed again.

Although the turnout at the elections was relatively low-both in the District (62 per cent) and nationally (61 per cent) - the elections were somehow present in everyone's minds, at every corner, in every conversation. After voting, the men sat together to speculate about the outcomes. Many people knew someone on 'election duty', and rapid exchanges of text messages started to inject bits of evidence into the 
latest predictions. People knew how many thousands had voted for whom in which area and soon their friends and relations from Muslim pockets elsewhere in the country started sending their estimates over. People were making bets and jokes, boasting about the certain victory of their favourite, while their companions would not believe any of it and predicted a dramatic loss of face. When I walked through Muthur with a known Niyas supporter, one of the groups promised him: 'If Niyas gets even 10,000 votes, I will buy you a van.' All roared with laughter including - if blushingly — my friend. Election day thus brought together a fascinating mix of the dignified performance of citizenship, street-corner joking, and speculation-and the anticipation of possible trouble, because past experience had shown that the celebration of electoral triumphs could easily degenerate into another clash. People in fact started to brace themselves for the prospective outcomes. Some of them even put up new posters of the candidates they thought would win, not because they voted for them, I was told, but to prevent themselves from being accused of disloyalty!

The official results were announced on national television throughout the night, but the next morning, the Trincomalee District results were still not out. The Elections Commissioner had ordered a re-poll after an incident in Kumburuputty, south of Kuchchaveli. A small group of (reportedly drunk) people had come and intimidated the voters, telling them to 'vote for number seven' (Poonchanilama). The incident attracted some attention, because it was one of two places where a re-poll was ordered (a bigger disruption took place in Nawalapitiya, near Kandy), but everyone knew the re-election on 20 April would make no difference: only 977 voters were registered at the polling station.

Counting in all other areas finished on 10 April. When the results were announced, the newspapers left no room for doubt. Page-wide headings of 'historic wins' and triumphant pictures applauded the government victory. Official results for Trincomalee (and Kandy) were withheld on that date, but the text message circuit made them a public secret. The local pundits had proven their predictive skills. The government had indeed secured two seats, while the United National Front (United National Party and the Muslim Congress) and the Tamil United Liberation Front both got one. It was also little surprise that Gunawardana won one of the government seats (19,734 preference votes) and that veteran Tamil leader Sampanthan secured the Tamil United Liberation Front seat (24,488 votes). As predicted, Kinniya's Muslim Congress man M. S. Thowfeek topped the United National 
Front list $(23,588)$, though his junior townsman Imran Maharoof (heir of the Maharoof dynasty) came close $(19,665)$. The revelation was that Poonchanilama, the only candidate from outside the region, captured the other government seat. With 22,820 votes, he in fact came well ahead of Gunawardana. The present member of parliament Najib Majeed—who had been accused of sleeping in parliament-was sent home $(15,906)$; his townsman Sabarula $(8,829)$, and Muthur's candidates Thideer Thowfeek $(5,096)$ and Niyas $(4,299)$ all placed last on the government list.

Gelebrations started throughout the District. Elected candidates travelled around to thank their voters. These festivities also raised some concerns: if a Muslim Congress figurehead visited a mosque in a government-affiliated area, this could easily lead to trouble. One such incident occurred in Kuchchaveli, I was told by a Muslim woman living there. Muslim Congress supporters came with a caravan of ten or $\mathbf{1 5}$ cars, collecting more and more people on the way, to celebrate M. S. Thowfeek's victory. They expected a festive welcome in this Muslim pocket, but instead encountered a group of government supporters, who started to throw stones at them. Such escalations were reported to me with an undertone of disapproval, lamenting the divisive force of politics. Tellingly, the sermon at the Jumma prayer in Muthur the day after the elections was about unity, my research assistant told me. 'The imam said Muslims should be peaceful after the elections. We are all brothers. We had the elections, but we all want to live here together. We are all Muslims. We will face each other again. We'll be at each other's funerals.'

\section{Post-election manoeuvring}

Nationwide, the government secured 144 seats (but would soon reach a two-thirds majority of $15^{\circ}$ seats as opposition members of parliament started crossing over). The United National Front's seats dwindled to just 6o, of which eight (including two national seats) were Muslim Congress. The Sinhala leftist Janatha Vimukthi Peramuna-with Sarath Fonseka at the helm-retained a mere seven members of parliament. The Tamil United Liberation Front secured most of the Tamil vote with 14 seats. None of the numerous other factions and independent candidates managed to get elected.

In Trincomalee, the composition of the government candidate list had ruptured the Muslim vote. Respondents from the smaller Muslim 
pockets blamed the Kinniya electorate, which had failed to stand united (with about 12,400 votes for both the government and the United National Front). They had provided the government with sufficient votes to take two seats, but failed to make sure that at least one of these was Muslim. People from Kinniya explained that when they turned away from the 'lethargic' Najib, there was no good alternative on the government list. The second Kinniya candidateSabarula-was considered chanceless and the other two Muslim candidates were from Muthur.

For Muslim voters the result was an electoral tragedy: both government members of parliament were Sinhala (Poonchanilama and Gunawardana). The Muslims were practically cut off from government patronage and the District's only Muslim member (M.S. Thowfeek, Muslim Congress) sat in a severely weakened opposition. Neither 'rights' nor 'development' had been served. Hope was vested in two last resorts: a crossover or a national seat. Given the deplorable result, the United National Front had only nine national seats to distribute, of which the United National Party leadership gave two to the Muslim Congress. Hakeem, the leader of the Muslim Congress, faced the tedious task of meeting the demands of his fragmented and dispersed vote base. In Muthur, a big Muslim Congress meeting was held on 12 April to pressure Hakeem to grant Harees a national seat (with 10,820 votes, the town's candidate had come second on the list), but Hakeem decided otherwise. A crossover by the District's only Muslim member of parliament (M. S. Thowfeek) was the only remaining possible access to government, but he remained loyal to the Muslim Congress. Months later, all eight Muslim Congress members of parliament would leave the United National Front to join government ranks, but they got little in return for their belated support. Divisions within the Muslim community-between parties, between towns, between families-thus resulted in a deception. As a minority overshadowed by a Sinhala-led government and Tamil separatists, Muslims tend to emphasize their need to stand together, but internal division had reared its head once more.

\section{Interlacing storylines}

The preceding electoral narrative consists of several interlacing storylines, and-importantly-there are tensions between them. First, there is the narrative of performing citizenship. Much in line with the 
anthropological literature that conceives of elections as a political ritual, elections provide a stage for people to exercise their franchise and thus enact their membership of a nation. Poor villagers, whose opinion normally carries little power, are transported by public buses, present themselves in front of state officials at the polling station, and by casting their vote, they take part in a national political ceremony, which is televised and affects the most powerful people in the country. Seen in this light, it is unsurprising that we witnessed families dressed up in their best clothes, exhibiting decorum, dignity, and duty. These particular elections carried an additional symbolic charge. They marked the government's military victory over 'terrorism', which enabled President Rajapaksa to belabour his patriotic credentials. There is of course a difference between 'citizens' and 'patriots' and this became quite clear in the way the government treated its political opponents. Rajapaksa's presidential re-election set the tone for the parliamentary election campaign. Fonseka ended up in jail and the opposition crumbled. The channels of patronage tightened. Supporters got kiribath, opponents got transferred.

Muslim politics comprises a second storyline. The Muslims navigate between the ethno-nationalism of the Sinhala majority and the ethnoseparatism of the Tamil minority. In short, the resulting tensions pivot on a trade-off between Muslim rights (mainly driven by anxieties over Sinhala or Tamil domination) and development (the need to be in government and secure benefits). The Muslim Congress originated as a political project to give voice to a besieged minority group and a significant number of Muslims hang on to the minority rights discourse, because 'the government will always think about the majority'. Fear of 'colonization' and fishing bans reinforced their concerns over Sinhala dominance. In line with other recent work on Sri Lankan Muslims, ${ }^{30}$ activating the boundary between Muslims and other ethnic groups comes to the fore as a vital part of the political equation. Yet, on the other hand, Muslim voters see the need for patronage, and in the post-war political landscape, many felt 'opposition is pointless'. Muslim politicians have to walk a tightrope, because they cannot afford to drop the Muslim identity issue nor disengage from minority-related issues, but an overly militant position blocks access to government largesse.

\footnotetext{
${ }^{30}$ Haniffa, 'Piety as Politics'; Hasbullah and Korf, 'Muslim Geographies'; Klem, 'Islam, Politics and Violence'; McGilvray, 'Sri Lankan Muslims'.
} 
While the competition for patronage partly explains the fissures in the Muslim polity, this is clearly not the whole story. After all, many people vote for candidates who would neither be able to deliver on minority rights, nor on material welfare. That brings us to the third electoral storyline: town-based identities, political families, and personal loyalties. These dynamics play a significant role in people's voting decisions and these intra-Muslim forms of belonging severely complicate the preceding storylines. The rivalry between Muslim towns is fierce. Kinniya's demographic weight has long fuelled the exclusion of smaller settlements. These towns, in turn, are made up of voting blocks along lines of class and/or neighbourhoods. And these patterns are complicated by political families to whom voters feel loyal or indebted. Seemingly mundane considerations-'my brother married his sister'-thus intervene in more fundamental political concerns over the plight of the Muslim community.

During the 2010 elections, the Muslim vote was divided between government (patronage) and opposition (minority rights), by rivalry between a big town (Kinniya) and smaller constituencies (Muthur), and by loyalties to contentious political dynasties. This latter dynamic was complicated by a local succession crisis in Kinniya. Imran, the Maharoof's coming man, was still very junior and Abdul Majeed's son Najib had failed to deliver as a member of parliament. With no obvious replacement from Kinniya on the government list, the vote dispersed. In the end, Kinniya lost its direct access to government. The smaller towns tended to vote for the Muslim Congress, but ironically the only Muslim Congress candidate to be elected was from Kinniya (M. S. Thowfeek). To the agony of my Muslim respondents, this candidate was the only Muslim member of parliament, even though Trincomalee District is one of very few places in Sri Lanka where Muslims form the biggest ethnic group (45 per cent). It was unprecedented that both government members of parliament from Trincomalee were Sinhalese. And the biggest winner was in fact an 'imported' politician: Susantha Poonchanilama from Ratnapura.

\section{Conclusions}

The flurry of activity described in this article confirms that elections involve more than collective deliberation over the composition of government. Spencer's conceptualization of elections as 'moral dramas of identity and difference' provides an insightful vantage point. 
Elections involve the crafting (and recrafting) of political identities, the activation (and deactivation) of political boundaries, and the forging (or severing) of political loyalties. Rather than focusing on the exclusive realm of rational interests and consensus-seeking, this article places central emphasis on the antagonism between 'us' and 'them', friends and foes.

The crucial political question is: which 'us' and which 'them'? This article's narrative brought forward different-and often contradictory-ways of defining political communities. The enactment of national citizenship, the preoccupation with 'the Muslim people', and the tensions around personal ties to locality-based political families propagated different political identities and affinities. During the election period, different kinds of antagonism continued to play a role. The prevalence of one us-them divide over other antagonisms clearly is an outcome of hard political work. Let me elaborate on this in the two conclusions below.

First, the interaction between these different identity layers makes the person, the community, and the nation more significant to each other. For a brief period, landless peasants and fishermen become citizens with a vote. Family relations are no longer just about weddings and favours, they tap into the nation's politics. Turf battles between towns find a new platform for contestation. Big men visit tranquil villages to deliver speeches and they actually keep last-minute promises. The claiming of territory by displaying posters, the show of force through massive rallies, the performance of loyalty by sitting on stage, and the decorum of queuing up for the ballot booth-such political performance makes voters part of a national contest and that is why these acts assume prominence. This conclusion tallies very well with the anthropological body of work on the ritual qualities of elections. ${ }^{31}$ Voting indeed is more than arithmetic, it comprises the performance of franchise and the dignified enactment of citizenship.

Second, the confluence of different storylines sheds light on the sense of rupture and disturbance that tends to accompany elections. It elucidates why communities-however adamant they are on preserving their unity-fall prey to the divisive forces of politics. ${ }^{32}$ Trincomalee's Muslims had to show their colours on multiple fronts. They are quite adept at this chameleon-like behaviour, but elections

\footnotetext{
${ }^{31}$ Banerjee, 'Democracy, Sacred, and Everyday'; Bertrand, Briquet and Pels, Cultures of Voting; Spencer, Anthropology, Politics and the State.

${ }^{32}$ Spencer, Anthropology, Politics and the State.
} 
cause difficulty, because their allegiances may clash. Being a loyal family member, a good townsman or a respectable Muslim is difficult enough within one of the storylines, but being them all at once can create trouble when they engender divergent voting imperatives. This opens up a whole register of contradictions. It was these contradictions that left Muslims voters with such a disappointing outcome in April 2010, which also harboured a threat to their everyday lives. There were several violent clashes and people feared that 'wrong' alignments would invoke punitive actions. The story of communities putting up posters after elections to avoid accusations of being oppositional was one stark reminder that there was more at stake here than parliamentary seats.

This case study raises more fundamental observations about politics in Sri Lanka and South Asia at large. The interaction between different kinds of identity struggles is central to 'the political'. Apparent 'master antagonisms'-be they ethno-separatism in Sri Lanka, ${ }^{33}$ communal riots in Gujarat ${ }^{34}$ or caste politics in West Bengal or Uttar Pradesh ${ }^{35}$ remain connected to other us-them rivalries and political trajectories. This opens up additional dimensions of rupture and contestation: the political landscape is complicated by even more forms of struggles, which are not a mere derivative of national politics. But it also opens up space for political performances across the entrenched lines of contention, for example, through the dignified enactment of national citizenship, or through more localized registers that offset the received political categories. Although the elections were a time of licence and antagonism, Trincomalee's voters also realized they had to keep political divisions within bounds. They knew the imam was right in the Jumma sermon after the elections: after all, they would all be seeing each other again at the next funeral or local festivity. The interaction between multiple forms of political antagonism thus not only sheds light on the moral dramas of elections, it also directs us to the long periods between the political highpoints of election fever, periods in which people also enact different identities and belongings, but often manage to keep the unruly and divisive potential of the political at bay.

\footnotetext{
${ }^{33}$ Bastian, 'Electoral Systems'; Uyangoda, 'Ethnic Conflict'; Venugopal, 'Cosmopolitan Capitalism'; Wickremesinghe, Sri Lanka in the Modern Age.

${ }^{34}$ Berenschot, Riot Politics; Spodek, 'In the Hindutva Laboratory'.

${ }^{35}$ Doron, 'Caste Away?'; Roy, 'Caste and Power'.
} 